Original Research

\title{
Enhancing Phytoremediation Efficiency Using Regulated Deficit Irrigation
}

\author{
Xiwang Tang, Yu Song, Xin He, Lili Yi* \\ Department of Environmental Science, Hebei University of Environmental Engineering, Qinhuangdao, China
}

Received: 17 March 2018

Accepted: 14 May 2018

\begin{abstract}
In this study, Beta vulgaris $\mathrm{L}$. var. cicla was grown in cadmium-contaminated soil in a greenhouse. Regulated deficit irrigation was applied using three different irrigation levels (T1: $300 \mathrm{~L}, \mathrm{~T} 2: 200 \mathrm{~L}$, T3: $100 \mathrm{~L}$ per block during each irrigation event during the organogenesis stage; T1 was the control) to examine the effects on phytoremediation efficiency. According to the experimental results, the regulated deficit irrigation treatment (T2) decreased the Beta vulgaris L. var. cicla shoot biomass by $15.8 \%$, increased the $\mathrm{Cd}$ concentration in the shoots by $23 \%$, and maintained a constant root-shoot ratio. By contrast, T3 decreased the Beta vulgaris $\mathrm{L}$. var. cicla shoot biomass by $33.0 \%$, decreased the $\mathrm{Cd}$ concentration in shoots by $9.8 \%$, and increased the root-shoot ratio by $62.8 \%$. The $\mathrm{Cd}$ remediation potential efficiency (PE) of treatment T2 was $5.42 \mathrm{~g} \mathrm{ha}^{-1}-$ i.e., $39.7 \%$ higher than that of $\mathrm{T} 1$ and $61.8 \%$ higher than that of T3. This study indicated that regulated deficit irrigation can be used to enhance $\mathrm{Cd}$ phytoremediation and save water, but should be applied in a suitable way.
\end{abstract}

Keywords: cadmium, phytoremediation efficiency, regulated deficit irrigation, water conservation

\section{Introduction}

Excessive cadmium (Cd) in soil can reduce soil productivity and subsequently result in economic losses in agricultural production. Cadmium is highly toxic to both animals and plants [1-3], even at relatively low concentrations [4]. In addition, unlike organic pollutants, $\mathrm{Cd}$ can persist in soils for a long time [5], resulting in extensive damage. Industrial and agricultural activities are the major sources of $\mathrm{Cd}$ enrichment in soils [6-7]. Over the past five decades, global $\mathrm{Cd}$ emissions reached approximately $22,000 \mathrm{t}$ [8]. In China, $1 / 6$ of cultivated land is contaminated

*e-mail: txw@nwsuaf.edu.cn by heavy metals, of which approximately $1 / 4$ is polluted by $\mathrm{Cd}[9]$.

Among all soil remediation methods, phytoremediation is considered a cheap and sustainable technology [8], and it can preserve natural biodiversity while reducing pollution [10]. To enhance phytoremediation efficiency, plant growth regulators [11-13], bacteria, and fungi $[10,14,15]$ have been used mainly to enhance the biomass of the phytoremediation plants, as $\mathrm{Cd}$ accumulated by plants is strongly related to plant dry biomass [16] (i.e., a higher biomass can result in higher phytoremediation efficiency). However, in northwestern China, a well-known arid and semi-arid area, the lack of irrigation water could be the major factor that limits the biomass of phytoremediation plants, and the high cost of irrigation would increase the cost of phytoremediation. Therefore, an approach that increases phytoremediation 
efficiency without requiring high amounts of irrigation water is needed.

In general, the yield and nutrient uptake of a plant decreases under drought stress [17-19]. However, because the concept of regulated deficit irrigation was developed only in the 1970s, drought stress was still considered to have only a negative effect on plant biomass accumulation. This concept has successfully been used to maintain yield as high as possible while reducing the amount of irrigation [20]. The use of regulated deficit irrigation indicates that suitable drought stress during the plant organogenesis stage may enhance shoot biomass or at least not result in a considerable decrease, and as a result increase phytoremediation efficiency. To the best of our knowledge, data pertaining to the use of drought to enhance phytoremediation efficiency are limited.

Thus, to test the hypothesis that drought stress can promote $\mathrm{Cd}$ phytoremediation efficiency and reduce water use, a field study with three different irrigation treatments was carried out at a Cd-contaminated site. This experimental site was located in northwestern China - a well-known semi-arid area with an annual precipitation of approximately $500 \mathrm{~mm}$. There are numerous reports of soil pollution caused by heavy metals in this area [21-23]. The phytoremediation plant chosen in this study was Swiss chard (Beta vulgaris L. var. cicla), which is reported to be sensitive to soil $\mathrm{Cd}$ [24-26]. The results from this study will be meaningful for soil phytoremediation in arid areas.

\section{Experimental Procedures}

\section{Experimental Site}

The experiment was conducted in a greenhouse located in Yangling, Shaanxi Province (N34 17'28", E108 $\left.00^{\prime} 27^{\prime \prime}\right)$, where half of the agricultural irrigation water was underground [27]. Soil in the greenhouse was polluted by $\mathrm{Cd}$, and the pollution status was reported in Tang et al. [16, 23]. The soil was classified as loess soil, and some of the physical and chemical properties are listed in Table 1. The soil total $\mathrm{Cd}$ concentration was $1.87 \mathrm{mg} \mathrm{kg}^{-1}$; DTPA-Cd was $0.36 \mathrm{mg} \mathrm{kg}^{-1}$. The experimental field was located in a semi-humid area with an average annual precipitation of approximately $600 \mathrm{~mm}$ and an average annual evaporation of approximately $900 \mathrm{~mm}$.

\section{Experimental Layout}

The experiment consisted of one factor, i.e., irrigation (T1: apply $300 \mathrm{~L}$ per block each time, T2: apply $200 \mathrm{~L}$ per block each time, T3: apply $100 \mathrm{~L}$ per block each time; T1 was the control), with a randomized block design and three replications. The study was carried out from April to July 2016, and the test period spanned the $2^{\text {nd }}$ to $6^{\text {th }}$ week after the chard was transplanted from the seedling nursery into each plot, i.e., the organogenesis stage of the chard. During time-out of test period, all the chard in plots were irrigated according to treatment T1. Each plot was $2 \mathrm{~m}$ wide and $5 \mathrm{~m}$ long. Field ridges (0.5 m wide) were used to separate the plots.

The chard was cultured according to the following method:

A) Chard seeds were sown in soil next to the experimental plots. The cultivation area was covered with polyethylene plastic film to maintain moisture before germination. When necessary, water was sprayed to maintain the soil water holding capacity at $60 \%$.

B) When the seedlings matured and reached the fourleaf stage, they were transplanted into the plots. Before transplanting, the surface soil of the nine plots was well ploughed using a machine to ensure uniformity. The chard planting distance and row spacing were $40 \mathrm{~cm}$ and $30 \mathrm{~cm}$, respectively.

C) One week after chard transplanting, the 9 plots were randomly divided into three groups and irrigated according to the treatment designation, i.e., T1, T2, or T3. Irrigation was applied during the test period at 17:00 on May 17, May 24, May 31, June 7, and June 14. The irrigation method was flooding. No fertilizer was applied before or during the growth period in order to exclude the effect of fertilizer on chard $\mathrm{Cd}$ uptake.

\section{Determining Leaf Chlorophyll Content}

Ten chard plants were randomly selected from each plot to determine the leaf chlorophyll content. The chlorophyll content of all mature leaves was measured using a SPAD-502 chlorophyll meter, and the average value was calculated.

\section{Sampling and Sampling Pre-Treatment}

Three chard plants were randomly selected from each plot, and the entire plants were carefully harvested by hand. Each chard plant was cleaned carefully using distilled water and high purity water to remove surface dirt. After air-drying, each sample plant was divided into shoots and roots and then dried at $80^{\circ} \mathrm{C}$ to a constant weight. The fresh and dry biomass of each plant was measured. The dried samples were crushed using a stainless-steel plant tissue grinder (LD-Y500A, Shanghai, China). All samples were treated similarly.

After sampling, the aboveground parts of the remaining chard plants in each plot were harvested using a knife and were weighed to calculate the yield.

\section{Cd Analysis}

Cadmium was analyzed following the method published by Tang et al. [16]. A crushed plant sample $(0.5 \mathrm{~g})$ was added to a quartz container and mixed with $9 \mathrm{ml} \mathrm{HNO}_{3}(\mathrm{GR})$ and $3 \mathrm{ml} \mathrm{HClO}_{4}(\mathrm{GR})$ and then digested 
Table 1. Surface soil properties of the experiment field $(0-20 \mathrm{~cm})$; data shown as mean $\pm \mathrm{SD},(\mathrm{n}=3)$.

\begin{tabular}{|c|c|c|}
\hline Parameter & \multirow{2}{*}{ Units } & Value \\
Soil type & & $7.83 \pm 0.1$ \\
$\mathrm{pH}$ (water: soil = 5:1) & & $23 \pm 1$ \\
\hline maximum field capacity & $\%$ & $1.23 \pm 0.03$ \\
\hline soil bulk density & $\mathrm{g} \mathrm{cm}^{-3}$ & $36.1 \pm 1.2$ \\
\hline soil organic matter & $\mathrm{g} \mathrm{kg}^{-1}$ & $1.72 \pm 0.06$ \\
\hline total nitrogen & $\mathrm{g} \mathrm{kg}^{-1}$ & $302.6 \pm 8.52$ \\
\hline Olsen phosphate & $\mathrm{mg} \mathrm{kg}^{-1}$ & $721.6 \pm 14.39$ \\
\hline available potassium & $\mathrm{mg} \mathrm{kg}^{-1}$ & $1.87 \pm 0.07$ \\
\hline Cd & $\mathrm{mg} \mathrm{kg}^{-1}$ & $0.36 \pm 0.03$ \\
\hline Available $\mathrm{Cd}^{\mathrm{a}}$ & $\mathrm{mg} \mathrm{kg}^{-1}$ & \\
\hline
\end{tabular}

aNote: extracted for $2 \mathrm{~h}$ at $25^{\circ} \mathrm{C}$ with DTPA

(DTPA-TEA-CaCl, $\mathrm{pH}_{2}$.3) as buffer solution

at $160^{\circ} \mathrm{C}$ until almost dry. The digested liquid was made up to a volume of $25 \mathrm{ml}$ using high-purity water. The Cd concentration in the liquid was detected using a flame atomic absorption spectrophotometer (AAS) (Z-2000, Hitachi, Japan) at a wavelength of $228.8 \mathrm{~mm}$. Standard material, GBW-10015, was purchased from a standard material center in Beijing, China, to control the analytical quality. The recovery rate was $95 \pm 5 \%$. The standard substance was made from spinach and can be used in the environmental analysis of leafy vegetables.

\section{Cd uptake Capacity}

To assess the Cd uptake capacity of the chard, the total $\mathrm{Cd}$ that was phyto-accumulated by a single chard plant $\left(\mathrm{PU}_{\mathrm{Cd}}\right)$ and the chard $\mathrm{Cd}$ remediation potential efficiency (PE) were calculated according to Eq. (1-2) [26].

$$
\begin{aligned}
\text { PUCd } & =[\mathrm{Cd}] \text { shoots }\left(\mu \mathrm{g} \mathrm{g}^{-1}\right) \times \text { BMshoots }(\mathrm{g}) \\
& +[\mathrm{Cd}] \operatorname{roots}\left(\mu \mathrm{g} \mathrm{g}^{-1}\right) \times \text { BMroots }
\end{aligned}
$$

$$
\mathrm{PE}=[\mathrm{Cd}] \text { shoots }\left(\mathrm{mg} \mathrm{kg}^{-1}\right) \times \text { yield }\left(\mathrm{kg} \mathrm{ha}^{-1}\right)(2)
$$

The extraction coefficient (EC), translocation factor (TF), and bioaccumulation factor (BAF) were calculated according to Eq. (3)-(5), respectively, in order to assess the effect of the irrigation treatments on the chard phytoremediation capacity $[15,28]$.

$$
\begin{gathered}
\mathrm{EC}=\frac{[\mathrm{Cd}]_{\text {plant }} \mathrm{mg} \mathrm{kg}{ }^{1}}{[\mathrm{Cd}]_{\text {Soil }} \mathrm{mg} \mathrm{kg}{ }^{1}} \\
\mathrm{TF}=\frac{[\mathrm{Cd}]_{\text {Shoots }} \mathrm{mg} \mathrm{kg}{ }^{1}}{[\mathrm{Cd}]_{\text {roots }} \mathrm{mg} \mathrm{kg}{ }^{1}} \\
\mathrm{BAF}=\frac{[\mathrm{Cd}]_{\text {plant }} \mathrm{mg} \mathrm{kg}^{1}}{[\mathrm{Cd}]_{\text {available in soil }}{ }^{1} \mathrm{mg} \mathrm{kg}{ }^{1}}
\end{gathered}
$$

\section{Data Analysis}

Data were statistically analyzed using the SigmaPlot 12.5 package (Systat Software Inc.) and Excel 2010. One-way analysis of variance and multiple comparisons (Duncan's Method) were used to compare the significance of the differences between groups $(\alpha=0.05)$.

\section{Results and Discussion}

Effect of regulated deficit irrigation on chard growth

The chard growth condition was based on characteristics such as biomass, root/shoot ratio, and the leaf chlorophyll content. Table 2 shows the individual biomass and root/shoot ratios of Swiss chard plants. It can be observed that in treatments T1, T2, and T3, the individual plant fresh biomass values were 639, 466, and $403 \mathrm{~g}$, respectively, with corresponding dry biomass values of 43.6, 36.7, and 29.2 g. Significant differences were observed among the three treatments with respect to the fresh and dry biomass of individual Swiss chard plants.

The root-shoot ratios were 2.0, 2.3, and 3.0 based on fresh weight and 4.3, 4.3, and 7.0 based on dry weight in $\mathrm{T} 1, \mathrm{~T} 2$, and $\mathrm{T} 3$, respectively. The root-shoot ratios of $\mathrm{T} 1$ and $\mathrm{T} 2$ were not significantly different, whereas the root-shoot ratio of $\mathrm{T} 3$ was significantly higher than that of $\mathrm{T} 1$ and $\mathrm{T} 2$. This indicates that chard plants in the T2

Table 2. Chard biomass and root/shoot ratios under three regulated deficit irrigation treatments (T1: 300 L, T2: 200 L, T3: $100 \mathrm{~L}$ per block during each irrigation event during the organogenesis stage; T1 was the control); FW: fresh weight, DW: dry weight $(\mathrm{n}=15, \alpha=0.05)$.

\begin{tabular}{|c|c|c|c|c|c|c|c|c|}
\hline \multirow{2}{*}{ Treatments } & \multicolumn{4}{|c|}{ Shoots } & \multicolumn{3}{c|}{ Roots } & \multicolumn{3}{c|}{ Root/shoot ratio } \\
\cline { 2 - 10 } & $F^{*}$ DW g g $^{-1}$ & DW/FW \% & FW g $^{-1}$ & DW g & DW/FW \% & FW\% & DW\% \\
\hline T1 & $639 \pm 12 \mathrm{a}$ & $43.6 \pm 4.9 \mathrm{a}$ & $6.6 \pm 0.2 \mathrm{~b}$ & $12.7 \pm 1.48 \mathrm{a}$ & $1.8 \pm 0.2 \mathrm{a}$ & $14.1 \pm 0.4 \mathrm{a}$ & $2.0 \pm 0.3 \mathrm{~b}$ & $4.3 \pm 1.0 \mathrm{~b}$ \\
$\mathrm{~T} 2$ & $466 \pm 17 \mathrm{~b}$ & $36.7 \pm 3.0 \mathrm{~b}$ & $8.1 \pm 0.1 \mathrm{a}$ & $10.8 \pm 0.94 \mathrm{a}$ & $1.6 \pm 0.4 \mathrm{a}$ & $15.2 \pm 5.1 \mathrm{a}$ & $2.3 \pm 0.3 \mathrm{~b}$ & $4.3 \pm 0.6 \mathrm{~b}$ \\
\hline $\mathrm{T} 3$ & $403 \pm 13 \mathrm{c}$ & $29.2 \pm 0.3 \mathrm{c}$ & $7.5 \pm 0.5 \mathrm{ab}$ & $12.0 \pm 1.05 \mathrm{a}$ & $2.0 \pm 0.3 \mathrm{a}$ & $17.1 \pm 0.7 \mathrm{a}$ & $3.0 \pm 0.3 \mathrm{a}$ & $7.0 \pm 1.2 \mathrm{a}$ \\
\hline
\end{tabular}




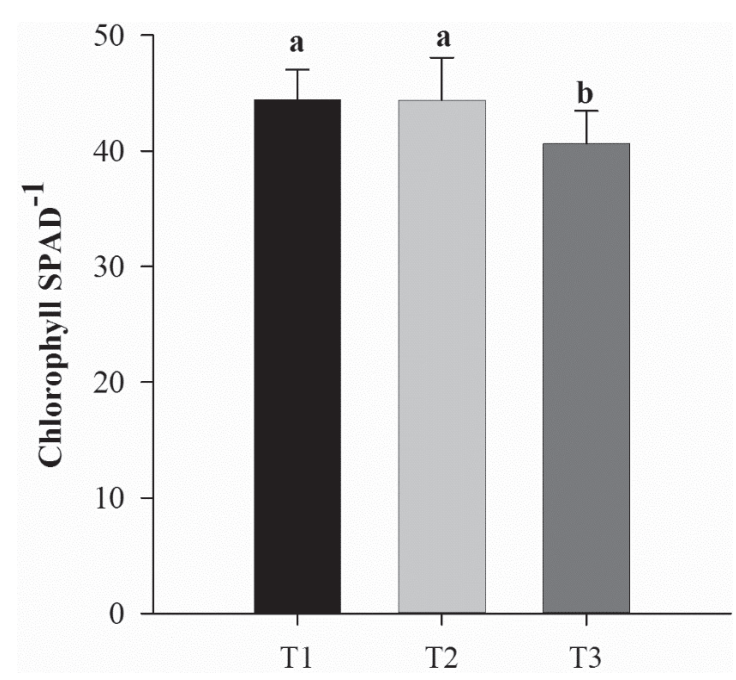

Fig. 1. Chlorophyll content in chard leaves under three regulated deficit irrigation treatments (T1: $300 \mathrm{~L}, \mathrm{~T} 2: 200 \mathrm{~L}, \mathrm{~T} 3: 100 \mathrm{~L}$ per block during each irrigation event during the organogenesis stage; T1 was the control); error bars stand for standard deviation $(\mathrm{n}=9, \alpha=0.05)$.

treatment could adapt to drought stress compared with the T3 treatment. The root-shoot ratio is an indicator of the proportion of plant material contained in the root versus the shoot. Hoffmann [29] observed that chard maintained an almost constant root-to-leaf ratio, whereas the transpiration coefficient changed after irrigation at $100 \%$ and $30 \%$ of the required water supply. This could explain why the chard in the T1 and T2 treatments had very similar fresh and dry root-shoot ratios. This result indicates that although the irrigation frequency declined from $\mathrm{T} 1$ to $\mathrm{T} 2$, the proportion of material allocated to roots and shoots did not change. However, the chard in the T3 treatment was severely affected by the decline of the irrigation frequency. The results indicated that the material transport from the root to the shoot was restricted; consequently, the chard plants in this treatment exhibited the highest root-shoot ratio.

The leaf chlorophyll content measured in the three treatments supports the results presented above (Fig. 1). The leaf chlorophyll content is the main indicator of photosynthesis; under severe drought stress, the leaf chlorophyll content decreases [19]. To compare the effect of the three treatments on the chard leaf chlorophyll content, the leaf chlorophyll was measured using a SPAD-502 chlorophyll meter; these data are shown in Fig. 1. From a statistical point of view, the leaf chlorophyll content of $\mathrm{T} 1$ was equal to that of $\mathrm{T} 2$ but significantly different from that of T3. This means that in this field experiment, when the irrigation supply changed from $\mathrm{T} 1$ to $\mathrm{T} 2$, the chlorophyll content of the chard leaves did not change significantly. However, when the irrigation supply further decreased to T3, the chlorophyll content decreased dramatically. Iron is required for the formation of chlorophyll, and the results indicated that in the $\mathrm{T} 2$ treatment, drought stress did not negatively affect the transport of iron from the root to the shoot.

\section{Effect of Regulated Deficit Irrigation on Cd Uptake}

The Cd content of chard shoots and roots is shown in Table 3. The shoot $\mathrm{Cd}$ contents in $\mathrm{T} 1, \mathrm{~T} 2$, and $\mathrm{T} 3$ were $1.12,1.37$, and $1.01 \mathrm{mg} / \mathrm{kg}$, respectively. The $\mathrm{T} 2$ shoot Cd content was $23 \%$ and $37 \%$ higher than that measured in $\mathrm{T} 1$ and $\mathrm{T} 3$, respectively. However, there was no significant difference in the shoot $\mathrm{Cd}$ content between $\mathrm{T} 2$ and $\mathrm{T} 1$ or between $\mathrm{T} 1$ and $\mathrm{T} 3$. This indicated that under regulated deficit irrigation, such as the T2 treatment, the shoot $\mathrm{Cd}$ content would increase, but when drought stress was increased, the shoot $\mathrm{Cd}$ content would decrease.

The chard root $\mathrm{Cd}$ contents in $\mathrm{T} 1, \mathrm{~T} 2$, and T3 were $1.70,1.24$, and $1.28 \mathrm{mg} / \mathrm{kg}$, respectively (Table 3). In contrast to the $\mathrm{Cd}$ content in the shoots, the $\mathrm{T} 1$ treatment resulted in the highest $\mathrm{Cd}$ content in the roots, significantly higher than that in T2 and T3. This indicated that the chard plants in the T2 treatment were subjected to drought stress, the treatments settings in this trial were reasonable.

The total $\mathrm{Cd}$ extracted by a single chard plant $\left(\mathrm{PU}_{\mathrm{Cd}}\right)$ was calculated (Eq. 1) based on the Cd content in both the roots and shoots. In T1, T2, and T3, the chard $\mathrm{PU}_{\mathrm{Cd}}$ values were 47.0, 51.6, and $30.6 \mu \mathrm{g} /$ plant, respectively (Table 3). Obviously, chard in the T2 treatment had the highest $\mathrm{PU}_{\mathrm{Cd}}$ value, which was $9.8 \%$ and $68.6 \%$ higher than that in $\mathrm{T} 1$ and $\mathrm{T} 3$, respectively.

From a statistical point of view, chard plants in the $\mathrm{T} 1$ and $\mathrm{T} 2$ treatments had the same $\mathrm{Cd}$ uptake capacity for phytoremediation purposes. However,

Table 3. Chard shoots and roots $\mathrm{Cd}$ concentrations and $\mathrm{PU}_{\mathrm{Cd}}$ and $\mathrm{PE}$ values under three regulated deficit irrigation treatments (T1: 300 L, T2: 200 L, T3: 100 L per block during each irrigation event during the organogenesis stage; T1 was the control); data shown as mean $\pm \operatorname{SD}(n=15, \alpha=0.05)$.

\begin{tabular}{|c|c|c|c|c|}
\hline Treatments & Cd in shoots $\mathrm{mg} \mathrm{kg}^{-1} \mathrm{DW}$ & $\mathrm{Cd}$ in roots $\mathrm{m} \mathrm{kg}^{-1} \mathrm{DW}$ & $\mathrm{PU}_{\mathrm{Cd}} \mu \mathrm{g} \mathrm{plant}^{-1}$ & ${\text { PE }(\text { shoots }) \mathrm{g} \mathrm{ha}^{-1}}^{\mathrm{T} 1}$ \\
\hline $\mathrm{T} 2$ & $1.12 \pm 0.09 \mathrm{ab}$ & $1.70 \pm 0.20 \mathrm{a}$ & $47.0 \pm 1.0 \mathrm{a}$ & $3.88 \pm 0.19 \mathrm{~b}$ \\
\hline $\mathrm{T} 3$ & $1.37 \pm 0.16 \mathrm{a}$ & $1.24 \pm 0.07 \mathrm{~b}$ & $51.6 \pm 4.3 \mathrm{a}$ & $5.42 \pm 0.43 \mathrm{a}$ \\
\hline
\end{tabular}




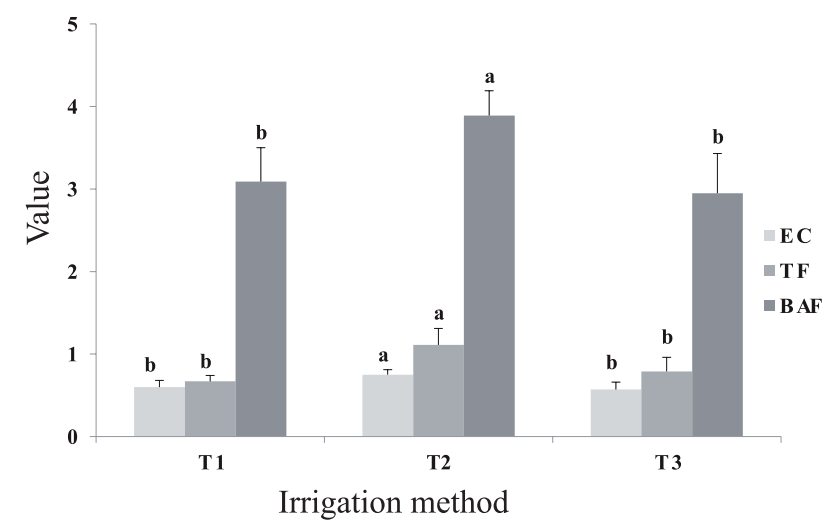

Fig. 2. Extraction coefficients (EC), translocation factor (TF), and bioaccumulation factor (BAF) in chard under different irrigation treatments (T1: $300 \mathrm{~L}, \mathrm{~T} 2: 200 \mathrm{~L}, \mathrm{~T} 3: 100 \mathrm{~L}$ per block during each irrigation event during the organogenesis stage; T1 was the control); data shown as mean $\pm \mathrm{SD}(\mathrm{n}=3$, $\alpha=0.05)$.

in practice, only the aboveground parts of chard are harvested; therefore, the $\mathrm{PU}_{\mathrm{Cd}}$ does not represent the real remediation efficiency. Therefore, PE is a more suitable indicator to describe the $\mathrm{Cd}$ phytoremediation efficiency of chard [26]. The $\mathrm{Cd}$ remediation PE of chard plants in the $\mathrm{T} 1, \mathrm{~T} 2$, and $\mathrm{T} 3$ treatments was $3.88,5.42$, and $3.35 \pm 0.74 \mathrm{~g} \mathrm{ha}^{-1}$, respectively (Table 3 ). The PE of chard plants was significantly higher in the T2 than in the T1 and T3 treatments. Although the $\mathrm{PU}_{\mathrm{Cd}}$ value did not differ between chard plants treated with $\mathrm{T} 1$ and $\mathrm{T} 2$, the PE value differed significantly between these treatments because of the different effect of the irrigation treatments on the shoot and root $\mathrm{Cd}$ contents. The PE value of T2 was $39.7 \%$ higher than that of $\mathrm{T} 1$.

\section{Effect of Irrigation Treatment on Chard Phytoremediation Capacity}

To explore the reason why $\mathrm{T} 2$ improved $\mathrm{Cd}$ phytoremediation efficiency, EC, TF, and BAF values for chard under the three irrigation treatments were calculated (Fig. 2). EC, TF, and BAF are three main indicators used to assess the metal uptake capacities of plants. Generally, higher EC, BF, and TF values indicate a higher phytoremediation efficiency $[12,26,28]$. The $\mathrm{EC}, \mathrm{TF}$, and BAF values of chard plants in the $\mathrm{T} 2$ treatment were $0.75,1.11$, and 3.89 , respectively, which were significantly higher than those in the $\mathrm{T} 1$ and $\mathrm{T} 3$ treatments. The EC, TF, and BAF values did not differ significantly between $\mathrm{T} 1$ and $\mathrm{T} 3$.

The EC, TF, and BAF values did not reach the standard of Cd-hyperaccumulators, and the $\mathrm{Cd}$ concentrations in chard shoots and roots were also very low in this study. The reason was that the soil $\mathrm{Cd}$ concentration in this study was $1.87 \pm 0.07 \mathrm{mg} \mathrm{kg}^{-1}$, and the DTPA extractable $\mathrm{Cd}$ was only $0.36 \pm 0.03 \mathrm{mg} \mathrm{kg}^{-1}$. These values are far lower than the soil $\mathrm{Cd}$ concentrations published by $[26,30]$, who also used chard in their experiments. The migration of $\mathrm{Cd}$ in alkaline soil is slower compared with acidic soil; under this condition, BAF is a more suitable indicator.

Putting the biomass and the leaf chlorophyll content into consideration, it can be easily seen that chard biomass accumulation was weakened, but the leaf chlorophyll content was not effected when changed from $\mathrm{T} 1$ to $\mathrm{T} 2$ treatment while both the chard biomass accumulation and leaf chlorophyll content were weakened when changed from $\mathrm{T} 1$ to $\mathrm{T} 3$ treatment. Under slight drought stress such as T2 treatment, the chard Cd uptake capacity would be increased, although the biomass accumulation rate may be restrained. For $\mathrm{T} 2$ treatment the reducing $\mathrm{Cd}$ accumulation amount caused by degradation of biomass can be denied by adding Cd concentration in shoots.

\section{Conclusions}

According to the results from this study, the regulated deficit irrigation treatment (T2) can be used to enhance phytoremediation efficiency while saving water. This treatment decreased the Beta vulgaris L. var. cicla shoot biomass by $15.8 \%$ but increased the $\mathrm{Cd}$ concentration in shoots by $23 \%$ and maintained a constant root-shoot ratio. The Cd remediation $\mathrm{PE}$ of $\mathrm{T} 2$ was $5.42 \mathrm{~g} \mathrm{ha}^{-1}$, i.e., $39.7 \%$ higher than that of $\mathrm{T} 1$ and $61.8 \%$ higher than that of $\mathrm{T} 3$.

This study indicated that regulated deficit irrigation can be used to enhance Cd phytoremediation and save water, but should be applied in a suitable way. Furthermore, this study also revealed that sufficient irrigation can reduce $\mathrm{Cd}$ uptake in plants, which will be useful in Cadmium pollution control. And for further research, we will test the applicability of our results on $\mathrm{Cd}$ phytoremediation by Cd-hyperaccumulators.

\section{Acknowledgements}

This research was result of Natural Science Foundation of Hebei Province of China (grant No. D2016415001), Program of China Hebei education department (grant No. QN2018141, QN2018121), Key Rresearch and Development Program funded by Hebei province of China (grant No. 18222906D) and Doctoral Starting-up Foundation of Hebei University of Environmental Engineering (grant No. BJ201801).

\section{Conflict of Interest}

The authors declare no conflict of interest. 


\section{References}

1. SARWAR N., ISHAQ W., FARID G., SHAHEEN M. R., IMRAN M., GENG M., HUSSAIN S. Zinc-cadmium interactions: Impact on wheat physiology and mineral acquisition. Ecotoxicology and Environmental Safety. 122, (122), 528, 2015.

2. SARWAR N., MALHI S.S., ZIA M.H., NAEEM A., BIBI S., FARID G. Role of mineral nutrition in minimizing cadmium accumulation by plants. Journal of the Science of Food and Agriculture. 90, (6), 925, 2010.

3. LI X., ZHOU Q., SUN X., REN W. Effects of cadmium on uptake and translocation of nutrient elements in different welsh onion (Allium fistulosum L.) cultivars. Food Chemistry. 194, 101,2016.

4. RAMOS I., ESTEBAN E., LUCENA J. J., GÁRATE A. Cadmium uptake and subcellular distribution in plants of Lactuca sp. Cd-Mn interaction. Plant Science. 162, (5), 761, 2002.

5. ADRIANO D.C., WENZEL W.W., VANGRONSVELD J., BOLAN N.S. Role of assisted natural remediation in environmental cleanup. Geoderma. 122, (2), 121, 2004

6. BOLAN N., KUNHIKRISHNAN A., THANGARAJAN R., KUMPIENE J., PARK J., MAKINO T., KIRKHAM M. B.\& SCHECKEL K. Remediation of heavy metal(loid) s contaminated soils - To mobilize or to immobilize? Journal of Hazardous Materials. 266, 141,2014.

7. DO NASCIMENTO DA SILVA E., HEERDT G., CIDADE M., PEREIRA C.D., MORGON N.H., CADORE S. Use of in vitro digestion method and theoretical calculations to evaluate the bioaccessibility of $\mathrm{Al}, \mathrm{Cd}, \mathrm{Fe}$ and $\mathrm{Zn}$ in lettuce and cole by inductively coupled plasma mass spectrometry. Microchemical Journal. 119, 152, 2015.

8. SINGH O.V., LABANA S., PANDEY G., BUDHIRAJA R., JAIN R.K. Phytoremediation: an overview of metallic ion decontamination from soil. Applied Microbiology and Biotechnology. 61, (5-6), 405, 2003.

9. WEI S., BAIMING C., LIN L. Soil heavy metal pollution of cultivated land in China. Research of soil and water conservation. 20, (02), 293,2013.

10. NUNES DA SILVA M., MUCHA A.P., ROCHA A.C., TEIXEIRA C., GOMES C.R., ALMEIDA C.M.R. A strategy to potentiate $\mathrm{Cd}$ phytoremediation by saltmarsh plants - Autochthonous bioaugmentation. Journal of Environmental Management. 134, 136,2014.

11. JI P., JIANG Y., TANG X., NGUYEN T.H., TONG Y., GAO P., Han W. Enhancing of Phytoremediation Efficiency Using Indole-3-Acetic Acid (IAA). Soil and Sediment Contamination: An International Journal. 8, (24), 909, 2015.

12. JI P., TANG X., JIANG Y., TONG Y.A., GAO P., HAN W. Potential of Gibberellic Acid 3 (GA3) for Enhancing the Phytoremediation Efficiency of Solanum nigrum L. Bulletin of Environmental Contamination and Toxicology. 95, (6), 810, 2015.

13. OKEM A., KULKARNI M.G., Van STADEN J. Enhancing phytoremediation potential of pennisetum clandestinum hochst in cadmium-contaminated soil using smoke-water and smoke-isolated karrikinolide. International Journal of Phytoremediation. 17, (11), 1046, 2015.

14. AGHABABAEI F., RAIESI F., HOSSEINPUR A. The significant contribution of mycorrhizal fungi and earthworms to maize protection and phytoreme- diation in Cd-polluted soils. Pedobiologia. 57, (4-6), 223 , 2014.

15. KHAN A.R., ULLAH I., KHAN A.L., PARK G., WAQAS M., HONG S., JUNG B.K., KWAK Y., LEE I., SHIN J. Improvement in phytoremediation potential of Solanum nigrum under cadmium contamination through endophytic-assisted Serratia sp. RSC-14 inoculation. Environmental Science and Pollution Research. 22, (18), 14032, 2015.

16. TANG X., PANG Y., JI P., GAO P., NGUYEN T.H., TONG Y. Cadmium uptake in above-ground parts of lettuce (Lactuca sativa L.). Ecotoxicology and Environmental Safety. 125, (0), 102, 2016.

17. FAROOQ M., WAHID A., KOBAYASHI N., FUJITA D., BASRA S.M.A. Plant drought stress: effects, mechanisms and management. Agronomy for Sustainable Development. 29, (1), 185, 2009.

18. AROCA R., ROUPHAEL Y., CARDARELLI M., SCHWARZ D., FRANKEN P., COLLA G. Effects of Drought on Nutrient Uptake and Assimilation in Vegetable Crops. In: Aroca Ricardo (ed): Springer Berlin Heidelberg, 171, 2012

19. MAFAKHERI A., SIOSEMARDEH A., BAHRAMNEJAD B., STRUIK P.C., SOHRABI E. Effect of drought stress on yield, proline and chlorophyll contents in three chickpea cultivars. Australian Journal of Crop Science. 4, (8), 580, 2010.

20. KANG S., SHI W., ZHANG J. An improved wateruse efficiency for maize grown under regulated deficit irrigation. Field Crops Research. 67, (3), 207, 2000.

21. HU Y., NAN Z., SU J., WANG S. Chelant-Assisted Uptake and Accumulation of Cd by Poplar from Calcareous Arable Soils Around Baiyin Nonferrous Metal Smelters, Northern China. Arid Land Research and Management. 28, (3), 340, 2014.

22. LI F., KANG L., GAO X., HUA W., YANG F., HEI W. Traffic-Related Heavy Metal Accumulation in Soils and Plants in Northwest China. Soil and Sediment Contamination. 16, (5), 473, 2007.

23. TANG X., TONG Y., JI P., LIANG L., PANG Y., NGUYEN T. Assessment of greenhouse heavy metal pollution in Guanzhong area and analysis of its spatial distribution on field scale using Geo-statistical software. Agricultural Research in the Arid Areas. 01, (34), $272,2016$.

24. BROADHURST C.L., CHANEY R.L., DAVIS A.P., COX A., KUMAR K., REEVES R.D., GREEN C.E. Growth and Cadmium Phytoextraction by Swiss Chard, Maize, Rice, Noccaea caerulescens, and Alyssum murale in $\mathrm{pH}$ Adjusted Biosolids Amended Soils. International Journal of Phytoremediation. 17, (1), 25, 2014.

25. LI Y., HU X., SONG X., HOU Y., SUN L. Phytoextraction Potential of Solanum nigrum L. and Beta Vulgaris L. Var. Cicla L. in Cd-Contaminated Water. Polish Journal of Environmental Studies. 24, (4), 1683, 2015. Phytoremediation of Cadmium-Contaminated Farmland Soil by the Hyperaccumulator Beta vulgaris L. var. cicla. Bulletin of Environmental Contamination and Toxicology. 88, (4), 623, 2012.

27. CHEN J. Research on Water-saving Index in Guanzhong Region at End of the "12 $2^{\text {th }}$ Five-year Plan" Based on Control of Water-using Amount. Journal of Water Resources \& Architectural Engineering. 11, (3), 135, 2013. 
28. KHAOKAEW S., LANDROT G. A field-scale study of cadmium phytoremediation in a contaminated agricultural soil at Mae Sot District, Tak Province, Thailand: (1) Determination of Cd-hyperaccumulating plants. Chemosphere. 138, (0), 883, 2015.

29. HOFFMANN C.M. Adaptive Responses of Beta Vulgaris L. and Cichorium Intybus L. Root and Leaf Forms to Drought Stress. Journal of Agronomy and Crop Science. 200, (2), 108, 2014.
30. VALDEZ-GONZÁLEZ J.C., LÓPEZ-CHUKEN U.J., GUZMÁN-MAR J.L., FLORES-BANDA F., HERNÁNDEZ-RAMÍREZ A., HINOJOSA-REYES L. Saline irrigation and $\mathrm{Zn}$ amendment effect on $\mathrm{Cd}$ phytoavailability to Swiss chard (Beta vulgaris L.) grown on a long-term amended agricultural soil: a human risk assessment. Environmental Science and Pollution Research. 21, (9), 5909, 2014. 
